PIOTR LIZAK

Uniwersytet Pedagogiczny, Kraków

\title{
Kształtowanie się aliansu strategicznego firm Nissan i Renault
}

Postępujący proces globalizacji gospodarki oraz związany z nim wzrost konkurencji na rynku zmusza przedsiębiorstwa do poszukiwania nowych struktur organizacyjnych, co prowadzi m.in. do uzyskania przez przedsiębiorstwa przewag konkurencyjnych oraz dostępu do nowych rynków zbytu. Konsekwencją tego są nasilające się procesy internacjonalizacji oraz koncentracji kapitału oraz osłabienie mechanizmów konkurencji działających na rynku globalnym.

Wśród wielu przedsiębiorstw, a szczególnie wśród korporacji transnarodowych, zaznacza się tendencja do podejmowania działalności kooperacyjnej. Aliansy strategiczne przedsiębiorstw nasilają różnorodne powiązania przestrzenno-produkcyjne równocześnie organizując światową przestrzeń gospodarczą (Zioło 2006). Prowadzi to do koncentracji kapitałowej przedsiębiorstw i zmiany ich struktury własnościowej.

Jak podkreśla J. Kraciuk (2005) alianse w gospodarce światowej zawierają głównie przedsiębiorstwa sektorów wysokiej technologii, tj. przemysłu telekomunikacyjnego, informatycznego, lotniczego i samochodowego. Wykorzystując postępujące procesy globalizacji i internacjonalizacji produkcji korporacje międzynarodowe będą dążyć do zwiększenia i pełnego wykorzystania posiadanych przewag konkurencyjnych poprzez działania prowadzące do zawarcia porozumień strategicznych (aliansów).

Relokalizacja i delokalizacja produkcji w skali całego świata prowadzi do szeregu przewag konkurencyjnych, tj. obniżenia kosztów pracy, dostępu do nowych rynków zbytu, zwiększenia skali produkcji, dostępności kontrahentów i in.

Przedmiotem niniejszych rozważań jest analiza kształtowania się i funkcjonowania aliansu międzynarodowych korporacji motoryzacyjnych Nissan - Renault, który prowadzi do integracji produkcji tych korporacji. Szczególna uwaga poświęcona będzie kształtowaniu się i funkcjonowaniu aliansu strategicznego analizowanych korporacji, przedstawieniu korzyści wynikających z zawarcia aliansu oraz zmian zachowań przedsiębiorstw na konkurencyjnym światowym rynku motoryzacyjnym. 
W literaturze przedmiotu alianse strategiczne definiowane są jako różne formy współpracy między niezależnymi przedsiębiorstwami, aktualnymi lub potencjalnymi konkurentami, pochodzącymi z tych samych lub różnych ogniw łańcucha wartości, którzy zdecydowali się wspólnie prowadzić wybrane przedsięwzięcie lub rodzaj działalności, łącząc, wymieniając i koordynując niezbędne do tego celu zasoby, środki, kompetencje, metody działania i umiejętności (Romanowska 1997). P. Dussauge i B. Garette (1996) definiują alians strategiczny jako porozumienie co najmniej dwóch niezależnych przedsiębiorstw realizujących przedsięwzięcie lub realizujących specyficzną działalność, koordynując przy tym kompetencje, sposoby i działania ale nie decydując się na fuzję czy sprzedaż działalności. Według Ernst \& Young alians przedsiębiorstw to związek kilku firm będących konkurentami i działających na tym samym rynku, zwykle o długotrwałym charakterze, którego celem jest realizacja wspólnego przedsięwzięcia. Integralną częścią każdego aliansu jest dzielenie się wiedzą i posiadanymi środkami z partnerami, tak aby przyniosły one korzyść wszystkim zaangażowanym stronom. Związek ten musi mieć ściśle określony cel, a szanse jego przetrwania gwarantuje zachowanie równowagi między partnerami (Ernst \& Young 2004). J.H. Dunning (1993) określa alianse przedsiębiorstw mianem „quasi internalizacji”. J. Kraciuk (2005) zaznacza, że alianse zawierane są dla osiągnięcia określonego celu strategicznego, zarówno ekonomicznego, jak i politycznego, obustronnie korzystnego dla partnerów. Istotne w pojęciu aliansu jest utrzymanie przez firmy niezależności, tzw. „nienaruszalnej autonomii" każdej z firm partnerskich, mimo umowy wiążącej jednych i drugich. W aliansach strategicznych przedsiębiorstwa partnerskie łączą się dla realizacji wspólnych celów, ale utrzymują swoją autonomię i chronią własne interesy. Potwierdza to L. Nyga (http:// www.knfm.friko.pl/prace-Dateien/Nyga\%20Lidia.doc z dnia 15.10.2011) zaznaczając, iż utworzenie aliansu strategicznego dwóch korporacji nie oznacza całkowitego wyeliminowania konkurencji pomiędzy nimi. Kooperacja dotyczy ściśle określonych dziedzin i mimo nawiązanego porozumienia, partnerzy ciągle pozostają potencjalnymi rywalami. G. Hamel (za L. Nyga) zauważa, że spółki joint venture powinny być postrzegane jako nowy rodzaj konkurencji, gdyż przedsiębiorstwa partnerskie kooperując w pewnych obszarach, konkurują ze sobą w innych dziedzinach (Nyga, http://www.knfm.friko.pl/prace Dateien/Nyga\%20 Lidia.doc z dnia 15.10.2011).

Alianse strategiczne przedsiębiorstw występują w trzech zasadniczych typach:

- non-equity alliances - umowy np. o wspólnych badaniach, marketingu i innych działaniach tworzących łańcuch wartości każdego z partnerów. W tej grupie aliansów można znaleźć takie formy jak franchising i licencje, przy czym w przypadku licencji tylko wtedy, gdy jest ona aportem (wkładem) do umowy jednego z partnerów,

- w postaci przedsięwzięć joint venture,

- minority equity alliancs - alians może przyjąć formę częściowego wykupu, jednak przeprowadzonego w taki sposób, aby strony umowy dalej zachowały swoją niezależność (Kraciuk 2005).

Alianse strategiczne nie są nowym zjawiskiem, występowały one bowiem w gospodarce amerykańskiej już w latach 30-tych, lecz dopiero w latach 80-tych i 90-tych XX wieku ta forma współpracy stała się powszechna, obejmując swym zasięgiem najbardziej gospodarczo rozwinięte rynki świata, tj. USA, Japonii, a także krajów Unii Europejskiej.

Jak podkreśla wielu autorów znaczenie aliansów strategicznych międzynarodowych korporacji w światowej gospodarce jest bardzo istotne. J.H. Dunning (1993) w modelu opi- 
sywanym przez „eklektyczną teorię produkcji międzynarodowej” przyjmuje, iż „,przedsiębiorstwo rozważające możliwość ekspansji zagranicznej konfrontuje korzyści wynikające ze sprzedaży lub wydzierżawienia przez nie posiadanych przewag własnościowych z opcją ich transferowania za granicę wewnątrz własnej organizacji”. Korporacje podejmują decyzję o internacjonalizacji działalności poprzez bezpośrednie inwestycje zagraniczne, co może oznaczać zarówno fuzję czy przejęcie, jak i założenie nowego przedsiębiorstwa, gdy samodzielne wykorzystanie posiadanych przewag konkurencyjnych okazuje się dla nich bardziej korzystne (Dunning 1993; Kola, Kuzel 2006). Natomiast jeżeli przewaga konkurencyjna, wynikająca z samodzielnego wykorzystania posiadanych zasobów nie okazuje się korzystna, przedsiębiorstwo jest skłonne wybrać inną formę działalności gospodarczej, zapewniającej dostęp do nowych rynków zbytu, ale nie oznaczającej ekspansji przedsiębiorstwa poprzez bezpośrednie inwestycje zagraniczne. W przypadku, gdy potencjalne korzyści wynikające $\mathrm{z}$ internacjonalizacji produkcji przedsiębiorstwa nie przynoszą spodziewanych rezultatów międzynarodowe korporacje zawierają tylko umowę o współpracy z partnerem zagranicznym (Narula 2003; Kola, Kuzel 2006).

Z zawarcia aliansu strategicznego między przedsiębiorstwami mogą wynikać dla nich różnorodne skutki, zarówno pozytywne jak i negatywne (Tab. 1). Skutki pozytywne przejawiają się w zwiększeniu możliwości finansowych, zmniejszeniu kosztów działalności i podziału ryzyka, wejściu na nowe rynki zbytu i inne, a negatywne w udostępnianiu własnej wiedzy i kompetencji partnerowi, wzroście konfliktów w przedsiębiorstwie na tle kompetencyjnym $\mathrm{i}$ in. W literaturze przedmiotu do wspomnianych zagrożeń wynikających z zawarcia aliansu strategicznego przez przedsiębiorstwa wymieniono również możliwość utraty tożsamości organizacyjnej jednego z przedsiębiorstw, która skutkuje przejęciem mniejszego i słabszego kapitałowo przedsiębiorstwa, uczestnika aliansu, przez silniejszego partnera (Gomes-Casseres 2000). Innym zagrożeniem dla przedsiębiorstw przystępujących do aliansu jest dopasowanie organizacyjne, prawne i kulturowe obu partnerów aliansu. Brak wspólnej wizji prowadzenia działalności gospodarczej oraz brak jednolitych sposobów i metod zarządzania skutkują znacznymi stratami finansowymi przedsiębiorstw uczestników aliansu, a nawet mogą doprowadzić do rozpadu aliansu.

Tab. 1. Skutki zawierania aliansów strategicznych

\begin{tabular}{|l|l|}
\hline \multicolumn{1}{|c|}{ Skutki pozytywne } & \multicolumn{1}{|c|}{ Skutki negatywne } \\
\hline Znalezienie partnera wspierającego dany projekt & $\begin{array}{l}\text { Udostępnienie własnej wiedzy i kompetencji, } \\
\text { co może prowadzić do kradzieży pomysłów, } \\
\text { przejmowania klientów, a nawet szpiegowania }\end{array}$ \\
\hline Podział kosztów i ryzyka pomiędzy aliantów & $\begin{array}{l}\text { Wzrost konfliktów w przedsiębiorstwie i bałagan } \\
\text { kompetencyjny }\end{array}$ \\
\hline $\begin{array}{l}\text { Dostęp do niezbędnej wiedzy i specyficznych } \\
\text { umiejętności }\end{array}$ & $\begin{array}{l}\text { Dylemat lojalności wobec firmy czy wobec } \\
\text { aliansu }\end{array}$ \\
\hline Wejście na nowe rynki & $\begin{array}{l}\text { Problemy z ustaleniem długoterminowej strategii } \\
\text { i podziałem zysków }\end{array}$ \\
\hline $\begin{array}{l}\text { Zachowanie pewnego stopnia odwracalności } \\
\text { decyzji strategicznych }\end{array}$ & $\begin{array}{l}\text { Możliwe zagrożenie dla zmieniających się inte- } \\
\text { resów partnerów }\end{array}$ \\
\hline
\end{tabular}

Źródło: J. Rymarczyk (red.), Międzynarodowe stosunki gospodarcze, PWE, Warszawa 2006 
Przejawem procesów globalizacji i internacjonalizacji gospodarki jest tworzenie aliansu, który przyczynia się do zwiększenia konkurencyjności przedsiębiorstw.

Początki działalności korporacji Renault sięgają 1898 roku, gdy na przedmieściach Paryża w miejscowości Paris Billancourt rozpoczyna swoją działalność firma Société Renault Frères, produkująca motocykle, a w późniejszym okresie również samochody osobowe.

W latach powojennych aż do lat 80 . XX wieku firmę Renault charakteryzował dynamiczny rozwój. W latach 80 . XX wieku, w zakładach Renaulta rozpoczęto proces dywersyfikacji produkcji Grupy Renault, który doprowadził w 1984 roku firmę do poważnych problemów finansowych. W latach 80-tych Renault zaczął przynosić straty. Dopiero w 1987 roku wdrożono program naprawczy, wprowadzający zmiany w strukturze produkcji, skupiając działania firmy głównie na sektorze motoryzacyjnym, który zaczął się dynamicznie rozwijać. Koncern Renault przejął w 1999 roku 51\% akcji rumuńskiego producenta samochodów osobowych Dacia. Należy podkreślić, iż zakłady Renaulta zostały w 1945 roku znacjonalizowane, a w 2002 roku wielkość udziału państwa francuskiego w akcjonariacie firmy wynosiła 15,7\%. Sytuacja finansowa koncernu w 1998 roku była bardzo dobra. Koncern posiadał aktywa w wysokości 37,2 mld EUR i zysk na poziomie 1,3 mld EUR (Sulejewicz 2003).

Firma Nissan została założona przez Masujiro Hashimoto w 1911 roku, jako zakłady Kwaishinsha. W pierwszych latach działalności przedsiębiorstwo produkowało samochody osobowe marki DAT. W 1926 roku firma Kwaishinsha połączyła się z firmą Jitsuyo Jidosha z Osaki. Po II wojnie światowej firmę Nissan charakteryzował dynamiczny rozwój. Firma nawiązała współpracę $\mathrm{z}$ brytyjskim producentem samochodów osobowych firmą Austin i produkowała samochody osobowe na licencji brytyjskiej, stając się drugim co do wielkości producentem samochodów osobowych w Japonii. W 1958 roku przedsiębiorstwo rozpoczęło sprzedaż samochodów marki Datsun na rynku amerykańskim, a w 1961 roku na rynku meksykańskim. W 1970 roku firma Nissan na skutek procesów dywersyfikacji produkcji rozszerzyła działalność o produkcję silników okrętowych. W 1983 roku zaprzestano stosowania nazwy Datsun, a zaczęto używać Nissan, która do tej pory była zarezerwowana dla ciężarówek. W 1989 roku Nissan stworzył nową markę samochodów luksusowych o nazwie Infiniti, przeznaczoną na rynek amerykański. W 1999 roku koncern Nissan znalazł się w bardzo trudnej sytuacji, posiadając ponad 11 mld USD długu (Sulejewicz 2003).

Pomimo odmiennej sytuacji ekonomicznej obu koncernów 27 marca 1999 roku grupa Renault zawarła alians strategiczny z japońskim producentem samochodów Nissan. Zawarty alians według wyżej przedstawionej typologii należy zaliczyć do trzeciej grupy tj. minority equity alliance, gdyż nastąpił częściowy wykup akcji koncernu, ale strony aliansu zdecydowały się zachować niezależność.

Na powstanie aliansu firm Nissan i Renault w znacznej mierze wpłynęły procesy globalizacji gospodarki oraz procesy koncentracji kapitału i konsolidacji branży motoryzacyjnej na świecie. Ponadto koncern Renault dysponował znacznymi zasobami kapitału i dążył do pozyskania nowych rynków zbytu, poszukując partnera branżowego produkującego dobre jakościowo samochody osobowe w Azji, z ugruntowaną pozycją na rynku.

Nissan posiadał w tym czasie rozbudowaną ofertę produktów (samochody osobowe i ciężarowe), był znaną na całym świecie marką, wytwarzał dobre jakościowo produkty oraz posiadał ugruntowaną pozycję na dużych rynkach zbytu w Azji, Europie i Ameryce Północnej. 
Warto zaznaczyć, iż podpisana umowa pomiędzy koncernami Nissan i Renault uchroniła koncern Nissan przed groźbą niewypłacalności i bankructwem.

Przedmiotowy alians strategiczny firm Nissan i Renault został zawarty w dwóch etapach. Pierwszy etap obejmował lata 1999-2002, charakteryzował się dokapitalizowaniem koncernu Nissan. Etap ten przewidywał sprzedaż 36,8\% akcji koncernu Nissan za około 4,4 mld EUR koncernowi Renault, z jednoczesną możliwością zakupu w późniejszym czasie przez koncern Nissana pakietu akcji koncernu Renault. W kolejnych latach trwania aliansu firma Renault zwiększyła posiadanie akcji Nissana do 44,3\%. Etap ten przewidywał również wprowadzenie planu restrukturyzacji koncernu Nissana (Nissan Revival Plan), który zakładał przywrócenie płynności finansowej przedsiębiorstwa do 2002 roku oraz zmniejszenia wysokości jego długów o 50\% do 6 mld USD. Nissan na skutek planu restrukturyzacji zwolnił w Japonii 21 tys. pracowników zamykając 5 fabryk. Równocześnie powołano jedenaście mieszanych zespołów składających się z pracowników koncernów Nissan i Renault, podejmujących działania zmierzające do zidentyfikowania potencjalnych obszarów współdziałania obu firm. Jak podaje A. Sulejewicz (2003) w latach 2000-2002, korzyści wynikające ze współpracy obu firm wynosiły około 3,4 mld USD.

Drugi etap kształtowania się aliansu firm Nissan i Renault rozpoczął się w 2002 roku, kiedy to ogłoszono plany przejęcia przez Nissana 15\% akcji Renault. Głównym celem założonej strategii było wyrównanie kapitałowe obu partnerów. Przejęcie pakietu 15\% akcji koncernu Renault przez koncern Nissan nastąpiło rok wcześniej z uwagi na fakt, iż Nissan szybciej niż oczekiwano zmniejszył zadłużenie (Sulejewicz 2003). Głównym założeniem tej fazy kształtowania się aliansu było silne zintegrowanie obu przedsiębiorstw m.in. poprzez wzajemną wymianę akcji. Cel ten zrealizowano jednocześnie powołując spółkę Renault-Nissan b. v. w której obie korporacje posiadają po 50\% udziałów. Głównym zadaniem utworzonego przedsiębiorstwa jest podejmowanie decyzji strategicznych związanych z funkcjonowaniem aliansu, od strategicznego planowania przez realizowanie polityki finansowej przedsiębiorstwa do zarządzania wspólnymi przedsiębiorstwami zależnymi. Druga faza kształtowania się aliansu miała za zadanie wzmocnić obu producentów.

Obecnie alians strategiczny koncernów Renault-Nissan oparty jest na wzajemnym zaangażowaniu kapitałowym partnerów - koncern Renault posiada 44,3\% udziałów koncernu Nissan, zaś koncern Nissan posiada 15\% udziałów koncernu Renault (Ryc. 1). Koncentracja kapitałowa aliansu pozwoliła na nowe przejęcia. W 2008 roku koncern Renault przejął 25\% + jedną akcję akcji rosyjskiego producenta samochodów osobowych AvtoVaz. Kontynuując inwestycje firm wchodzących w skład aliansu w zakłady AvtoVaz, w najbliższym czasie planowany jest zakup kolejnych 25\% akcji rosyjskiego producenta samochodów osobowych. Pozwoli to wspólnym władzom aliansu przejąć pełną kontrolę nad zakładami w Rosji. W 2010 roku władze aliansu podpisały strategiczne porozumienie o współpracy z firmą Daimler. W ramach porozumienia Daimler przejął 3\% akcji aliansu, zaś koncerny Nissan i Renault objęły po 1,55\% akcji Daimlera. Współpraca Daimlera z Nissanem i Renault dotyczy konstrukcji nowych modeli małych samochodów użytkowych, budowy nowych silników oraz połączenia nakładów i wysiłków przy konstrukcji nowych samochodów elektrycznych. 


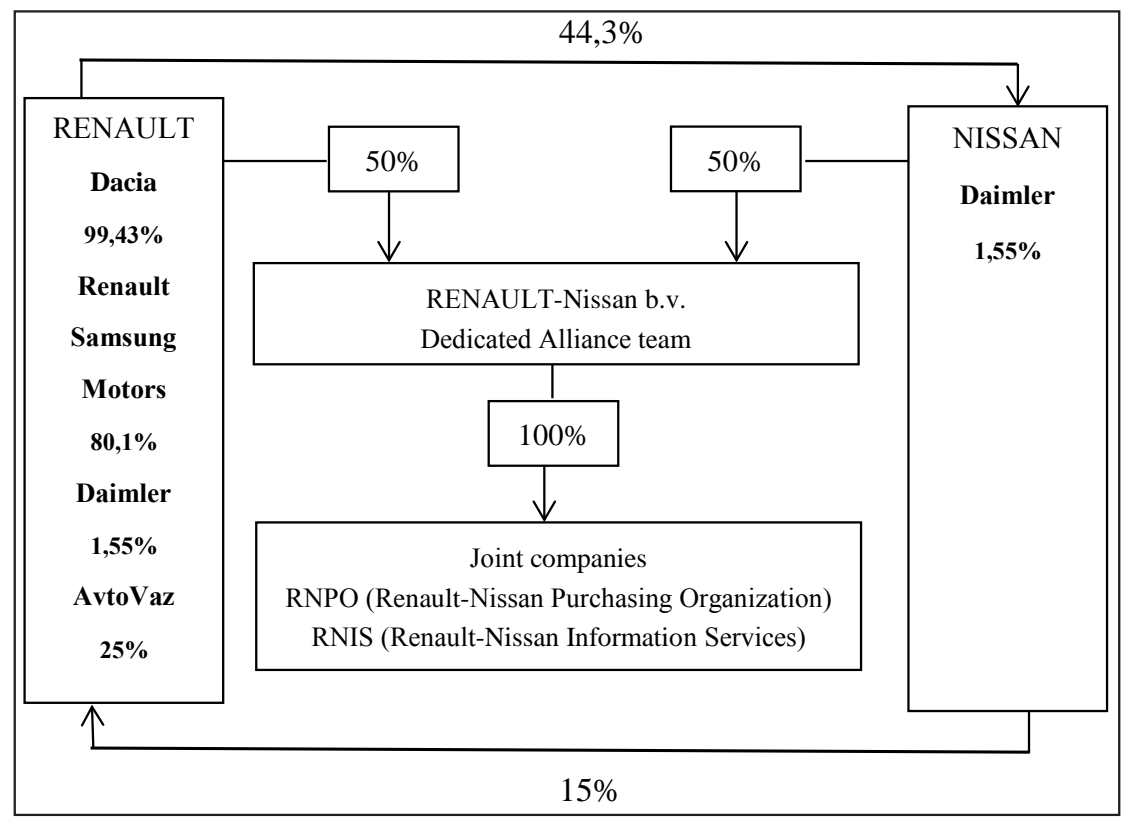

Ryc. 1. Struktura kapitałowa aliansu koncernów Nissan-Renault Źródło: opracowanie własne na podstawie Alliances Fact \& Figures 2009

Utworzony alians przynosi obu firmom znaczne korzyści wynikające z wykorzystania przez nie efektów skali produkcji oraz efektów synergii. Korzyści te wynikają ze standaryzacji produkcji, dzięki zastosowaniu wspólnych płyt podłogowych i układów napędowych, ze współpracy w zakresie zaawansowanych technologii i badań, ze standaryzacji metod produkcji, z rozwoju gamy modeli obu producentów oraz ze zwiększania zasięgu działania każdej z firm. Obie firmy dążą do zredukowania zróżnicowanej gamy podzespołów wykorzystywanych przy produkcji samochodów oraz koordynują działania zmierzające do ujednolicenia jak największej liczby wykorzystywanych części. Koncerny posiadają również wspólne zakłady produkcyjne, aby w pełni korzystać z lokalnego potencjału produkcyjnego. W 2009 roku zakład Renault w Brazylii produkował dwa modele Nissana, zaś zakład Nissana w RPA produkował dwa modele koncernu Renault. W 2009 roku wzajemnie produkowanych było 11 modeli samochodów. Przykładem współpracy obu firm jest również konstruowanie przez Renaulta nowych, niewielkich silników benzynowych na bazie jednostki Nissana, czy stosowanie przez oba koncerny wspólnych płyt podłogowych w produkowanych samochodach tj. płyta typu B (Nissan Tiida/Versa i Renault Clio) oraz płyta typu C (Renault Megane/Scenic i Nissan Qashqai).

Efekty synergii występują również w obszarze dokonywanych zakupów materiałów związanych z produkcją samochodów. Za całość zakupów obu przedsiębiorstw odpowiada jedna firma - Renault-Nissan Purchasing Organization, która koncentrując w 2009 roku zakupy Nissana w Korei Południowej wzmacniała sieci kooperantów koncernu Renault.

Koncerny motoryzacyjne Nissan i Renault integrują badania nad nowymi technologiami, posiadają wspólne systemy zarządzania, wspólny plan technologiczny i promocji na po- 
szczególnych rynkach zbytu, jednocześnie zachowując odrębność każdej marki. Koncerny te wspólnie poszukują miejsc efektywnej lokalizacji nowych zakładów aliansu, a także coraz częściej podejmują decyzje o relokacji produkcji. Podstawowym motywem relokacji i delokalizacji produkcji w zakładach koncernów motoryzacyjnych, w tym także w zakładach koncernów Nissan i Renault jest obniżenie kosztów produkcji i zwiększenia elastyczności działania przedsiębiorstwa. Innymi czynnikami wpływającymi na zmianę lokalizacji produkcji są: jakość i koszty pracy, chłonność i dostępność rynków zbytu, dostępność kontrahentów, zasady i wysokość opodatkowania przedsiębiorstw oraz dostępność i stan infrastruktury.

Struktura przestrzenna zakładów Renault w 1999 roku nie była zróżnicowana. Koncern Renault prowadził działalność produkcyjną głównie w Europie, skąd pozyskiwał 90\% dochodów (1998), a 57\% dochodów koncernu pochodziło z działalności na terenie Francji. Koncern prowadził inwestycje w Ameryce Południowej, ale nie posiadał zakładów w Ameryce Północnej i Azji (prócz Turcji) (Sulejewicz 2003).

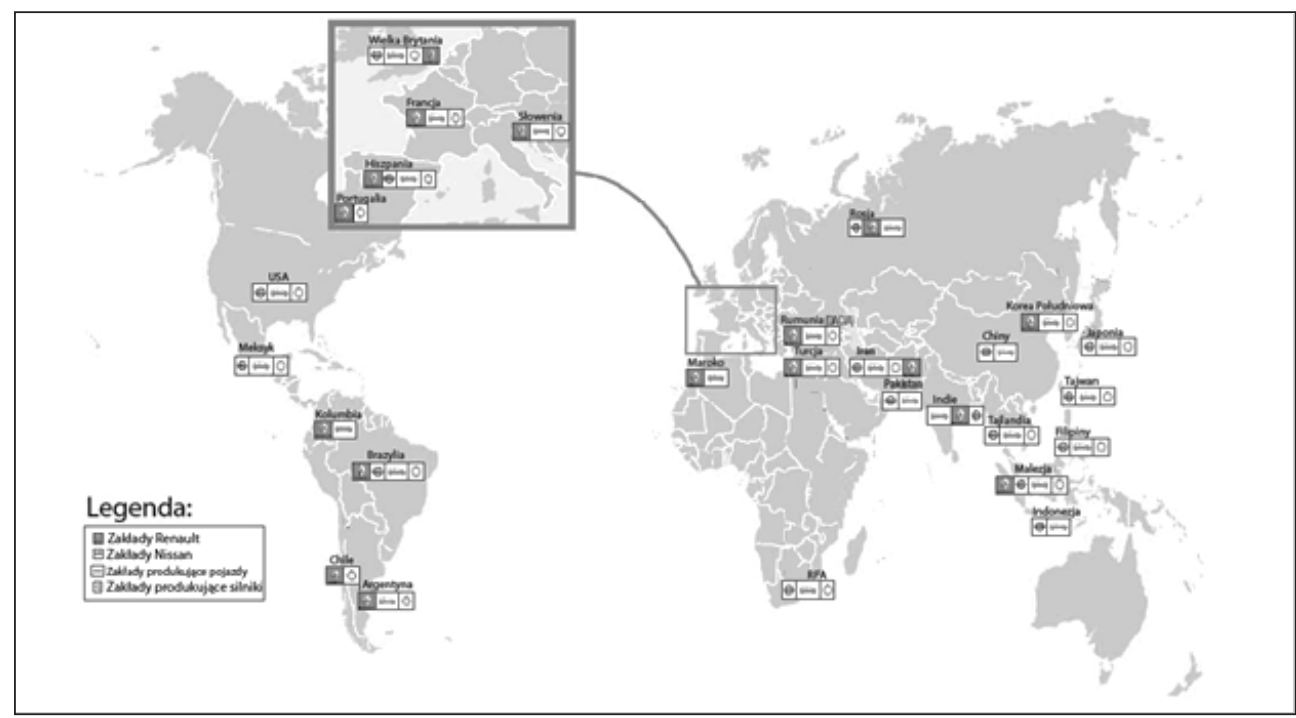

Ryc. 2. Struktura przestrzenna zakładów koncernów Nissan i Renault w 2010 roku

Źródło: opracowanie własne na podstawie Alliance Fact \& Figures 2009

Struktura przestrzenna zakładów koncernu Renault w 2010 roku uległa znacznym zmianom. Koncern posiada zakłady w nowych lokalizacjach, tj. w Rumunii (Dacia), Rosji (AvtoVaz), Wielkiej Brytanii, Korei Południowej, Iranie, Indiach i w RPA (Ryc. 2).

Po zawarciu aliansu z koncernem Renault, struktura przestrzenna zakładów koncernu Nissan również uległa zmianie. W 1999 roku Nissan posiadał zakłady produkujące samochody osobowe na 4 kontynentach, tj. w Afryce w RPA, Ameryce Północnej w USA i Meksyku, w Azji w Japonii i na Tajwanie oraz w Europie w Wielkiej Brytanii i Hiszpanii. W 2010 roku, koncern rozszerzył produkcję samochodów w Azji, poza Japonią, głównie w Chinach oraz rozwija produkcję w Ameryce Północnej w Meksyku i USA i Ameryce Południowej w Brazylii. 
Od zawiązania współpracy w ramach aliansu strategicznego zarówno koncern Nissan jak i koncern Renault sukcesywnie zwiększały produkcję (Ryc. 3). Pod względem wielkości produkcji Nissan w 1998 roku z produkcją 2089,00 tys. szt. samochodów osobowych klasyfikowany był na 7 miejscu na świecie $z$ udziałem w światowej produkcji wynoszącym 5,5\%, a koncern Renault z produkcją 1943,00 tys. szt. samochodów osobowych zajmował 8 miejsce z udziałem 5,1\% światowej produkcji. W latach 1998-2010 produkcja samochodów osobowych koncernu Renault zwiększyła się o 452,87 tys. szt. do 2395,87 tys. szt. w 2010 roku, co oznacza wzrost produkcji o 23\%. Produkcja koncernu Nissan w latach 1998-2010 zwiększyła się o 1053,13 tys. szt. do 3142,13 tys. szt. w 2010 roku, co oznacza wzrost produkcji o $50 \%$.

W 2010 roku koncern Nissan zajmuje 7 miejsce wśród największych przedsiębiorstw motoryzacyjnych świata produkując 5,3\% ogółu światowej produkcji - 3142,12 tys. sztuk, koncern Renault zajmuje 10 miejsce, produkując 4,1\% ogółu światowej produkcji - 2395,88 tys., a alians obu firm jest czwartym producentem samochodów osobowych na świecie, posiadając 9,4\% udział w produkcji świata.

W latach 1998-2010 globalna produkcja samochodów osobowych na świecie zwiększyła się o 20553,81 tys. szt. z 37925 tys. szt. w 1998 roku do 58478,81 w 2010 roku, tj. wzrosła o 54\%, zaś produkcja aliansu firm Nissan-Renault w badanym okresie wzrosła o 1506,00 tys. szt., z 4032,00 tys. szt. w 1998 roku do 5538,00 tys. szt. w 2010 roku co stanowi wzrost o 37,35\%, pomimo początkowych trudności finansowych firmy Nissan (Tab. 2).

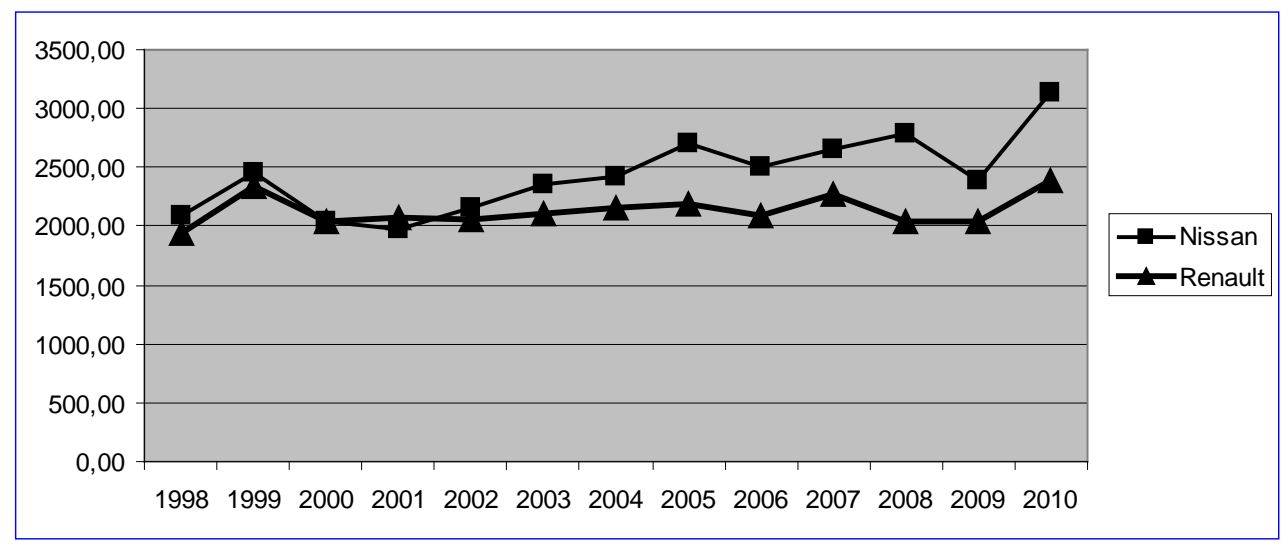

Ryc. 3. Produkcja samochodów osobowych koncernów Nissan i Renault w tys. szt. w latach 1998-2010

Źródło: opracowanie własne na podstawie OICA 
Tab. 2. Produkcja samochodów osobowych na świecie w tys. szt. w latach 1998-2010

\begin{tabular}{|r|r|r|r|r|r|r|}
\hline Lata & $\begin{array}{c}\text { Produkcja } \\
\text { światowa } \\
\text { w tys. szt. }\end{array}$ & $\begin{array}{c}\text { Wskaźnik } \\
\text { dynamiki } \\
\text { produkcji } \\
\text { świata }\end{array}$ & $\begin{array}{c}\text { Produkcja } \\
\text { koncernu } \\
\text { Nissan }\end{array}$ & $\begin{array}{r}\text { Wskaźnik } \\
\text { dynamiki } \\
\text { produkcji } \\
\text { koncernu } \\
\text { Nissan }\end{array}$ & $\begin{array}{c}\text { Produkcja } \\
\text { koncernu } \\
\text { Renault }\end{array}$ & $\begin{array}{r}\text { Wskaźnik } \\
\text { dynamiki } \\
\text { produkcji } \\
\text { koncernu } \\
\text { Renault }\end{array}$ \\
\hline 1998 & 37925,00 & - & 2089,00 & - & 1943,00 & - \\
\hline 1999 & 39759,85 & 104,84 & 2455,00 & 117,52 & 2347,00 & 120,79 \\
\hline 2000 & 41215,65 & 103,66 & 2043,89 & 83,31 & 2043,88 & 87,08 \\
\hline 2001 & 39825,00 & 96,63 & 1966,84 & 96,16 & 2070,37 & 101,30 \\
\hline 2002 & 41358,39 & 103,85 & 2164,62 & 110,06 & 2049,81 & 99,01 \\
\hline 2003 & 41968,67 & 101,48 & 2363,16 & 109,17 & 2110,56 & 102,96 \\
\hline 2004 & 44544,27 & 106,14 & 2423,89 & 102,57 & 2163,62 & 102,51 \\
\hline 2005 & 46862,98 & 105,21 & 2697,36 & 111,28 & 2195,16 & 101,46 \\
\hline 2006 & 49918,58 & 106,52 & 2512,52 & 93,15 & 2085,84 & 95,02 \\
\hline 2007 & 53201,35 & 106,58 & 2658,81 & 105,82 & 2276,04 & 109,12 \\
\hline 2008 & 52726,12 & 99,11 & 2788,63 & 104,88 & 2048,04 & 89,98 \\
\hline 2009 & 47772,60 & 90,61 & 2381,23 & 85,39 & 2044,11 & 99,81 \\
\hline 2010 & 58478,81 & 122,41 & 3142,13 & 131,95 & 2395,87 & 117,21 \\
\hline
\end{tabular}

Źródło: opracowanie własne na podstawie OICA

Produkcja samochodów osobowych koncernów tworzących alians w poszczególnych regionach jest zróżnicowana. Produkcja Renault w 2000 roku koncentrowała się w Europie, gdzie wyprodukowano 1775,10 tys. szt. samochodów, co stanowiło 86,85\% ogółu produkcji koncernu. Największą liczbę samochodów osobowych koncernu wytwarzały zakłady we Francji, gdzie wyprodukowano 1166,79 tys. szt., co stanowiło 57,09\% ogólnej produkcji koncernu. Udział zakładów Renault zlokalizowanych w Azji i Ameryce Południowej w ogólnej produkcji przedsiębiorstwa wyniósł po ok. 6\%, zaś zakład w Afryce wyprodukował ok. 0,21\% ogólnej produkcji koncernu w 2000 roku (Tab. 3).

W 2010 roku produkcja samochodów osobowych koncernu nadal koncentrowała się w Europie, gdzie wyprodukowano 1461,21 tys. szt. samochodów osobowych, co stanowiło $60,99 \%$ ogółu produkcji koncernu na świecie. Największą liczbę samochodów osobowych koncernu wytwarzały ponownie zakłady we Francji, gdzie wyprodukowano 475,19 tys. szt., co stanowiło 19,83\% ogólnej produkcji koncernu. Udział zakładów koncernu Renault zlokalizowanych w Azji wynosił 25,69\% ogółu produkcji koncernu, a zakładów w Ameryce Południowej 11,57\%. Produkcja koncernu Renault w Afryce stanowiła 1,74\% ogółu produkcji koncernu w 2010 roku.

W 2010 roku koncern Renault odnotował spadek ilości wytwarzanych samochodów osobowych w Europie z 1775,10 tys. sztuk w 2000 roku do 1461,21 tys. szt. w 2010 r., tj. spadek o 17,68\% oraz wzrost produkcji koncernu w Azji ze 138,48 tys. szt. w 2000 roku do 615,73 tys. szt. w 2010 roku, co stanowi ponad trzykrotny wzrost produkcji. Wspomniane zmiany produkcji koncernu Renault w latach 2000-2010 świadczą o zachodzących procesach relokacji i delokalizacji produkcji. O procesach delokalizacji i relokacji produkcji koncernu świadczy także spadek wielkości produkcji samochodów osobowych w Europie (spadek produkcji o 18\%), a zwłaszcza we Francji (spadek produkcji o 59,27\%) wraz ze wzrostem 


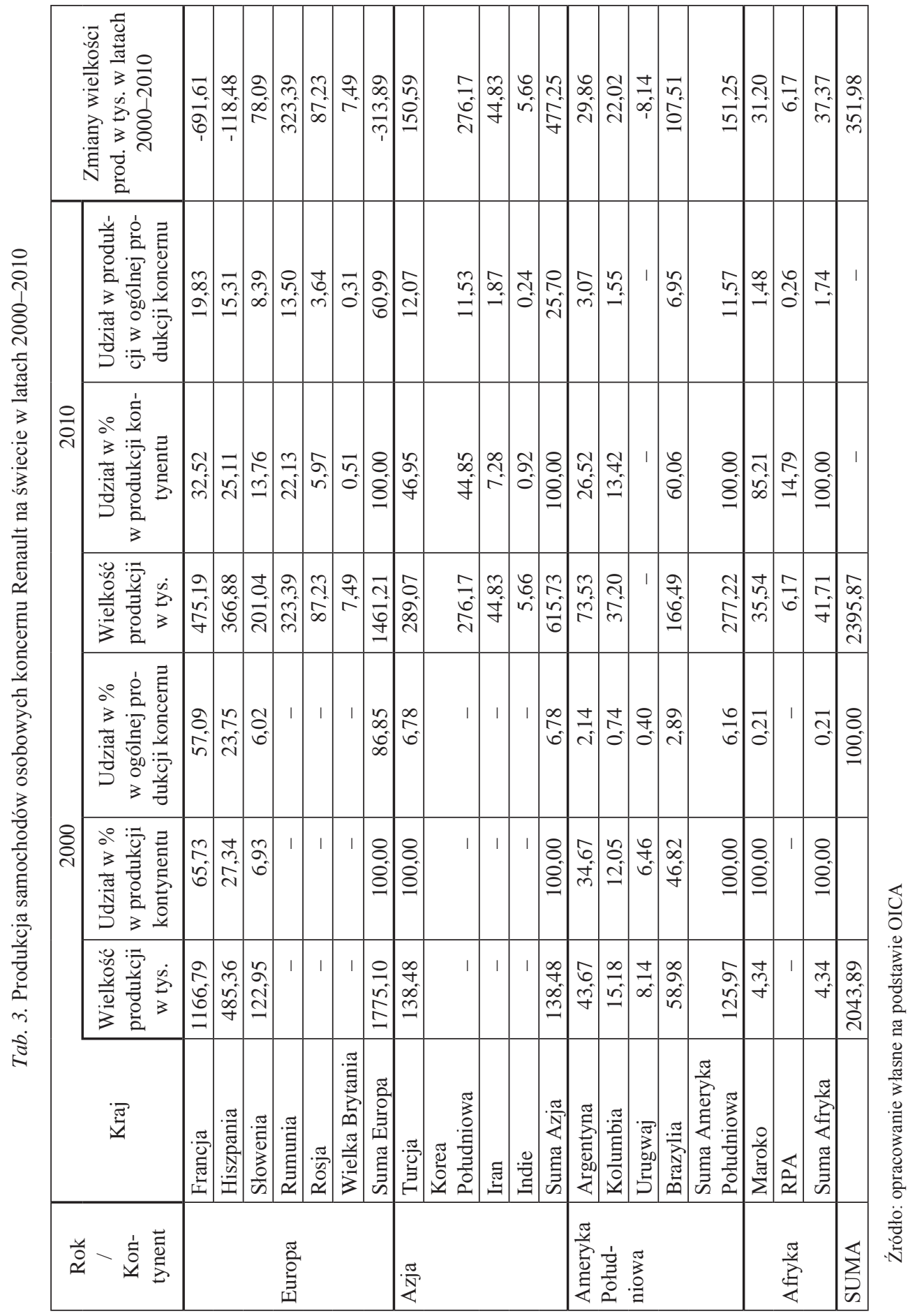




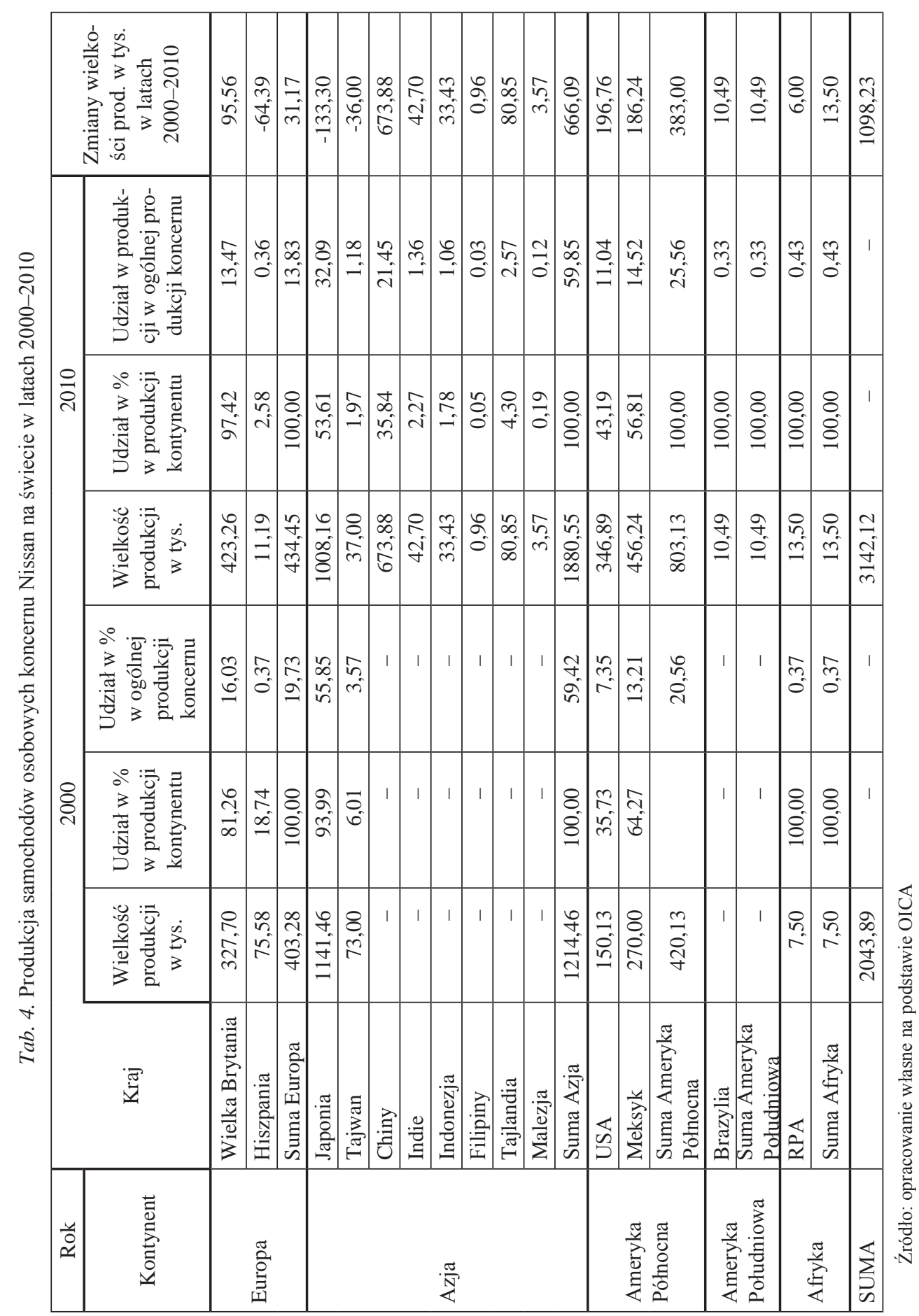


produkcji całego koncernu Renault. Jak wynika z przedstawionej analizy koncern Renault w latach 2000-2010 przenosił produkcję samochodów osobowych z Francji głównie w rejon Azji - ponad trzykrotny wzrost produkcji, Ameryki Południowej - wzrost produkcji o 20\%, oraz do Rumunii, gdzie produkowanych jest 13,5\% ogólnej produkcji koncernu.

Produkcja koncernu Nissan w 2000 roku koncentrowała się w Azji, gdzie wyprodukowano 1880,55 tys. szt. samochodów, co stanowiło 59,85\% ogółu produkcji koncernu. Największą liczbę samochodów osobowych koncernu wytwarzały zakłady w Japonii, gdzie wyprodukowano 1141,46 tys. szt. co stanowiło 55,85\% ogólnej produkcji koncernu. Udział zakładów koncernu Nissan zlokalizowanych w Ameryce Północnej i Europie w ogólnej produkcji przedsiębiorstwa wynosił po ok. 20\%, zaś zakłady w Afryce wyprodukowały ok. 0,37\% ogólnej produkcji koncernu w 2000 roku (Tab. 4).

Produkcja samochodów osobowych koncernu Nissan w 2010 roku nadal koncentrowała się w Azji gdzie wyprodukowano 1880,50 tys. sztuk samochodów osobowych, co stanowiło $59,85 \%$ ogółu produkcji koncernu na świecie. Największą liczbę samochodów osobowych koncernu wytwarzały zakłady w Japonii, gdzie wyprodukowano 1008,16 tys. szt., co stanowiło 32,09\% ogólnej produkcji koncernu. Udział zakładów koncernu Nissan zlokalizowanych w Ameryce Północnej wynosił 25,56\% ogółu produkcji koncernu, a zakładów w Europie 13,83\%. Znikomą wielkością produkcji odznaczały się zakłady koncernu Nissan w Ameryce Południowej, gdzie produkcja wyniosła 0,33\% ogółu produkcji koncernu oraz zakłady w Afryce gdzie produkcja stanowiła 0,43\% ogółu produkcji koncernu w 2010 roku.

Rozpatrując przestrzenne zmiany produkcji koncernu Nissan zaobserwowano spadek ilości wytwarzanych samochodów osobowych w Japonii z 1141,46 tys. szt. w 2000 r. do $1008,16 \mathrm{w} 2010$ roku, tj. spadek o $11,68 \%$ oraz wzrost produkcji koncernu w pozostałych krajach Azji z 73,00 tys. szt. w 2000 roku do 872,39 tys. szt. w 2010 roku, co oznacza ponad 10-krotny wzrost produkcji, w tym głównie w Chinach gdzie produkcja w 2010 roku wyniosła 673,88 tys. szt. Wyżej wymienione zmiany produkcji koncernu Nissan świadczą o poszukiwaniu przez ten koncern nowych rynków zbytu oraz miejsc nowych lokalizacji dla swoich zakładów. Efektem procesów relokacji produkcji koncernu Nissan jest spadek wielkości produkcji samochodów w Japonii wraz z dynamicznym wzrostem produkcji całego koncernu. Jak wynika z przedstawionej analizy koncern Nissan w latach 2000-2010 przenosił produkcję samochodów osobowych z Japonii głównie do Chin i pozostałych krajów Azji.

W wyniku zawiązania aliansu strategicznego oba koncerny odniosły korzyści w dziedzinie rentowności i kapitalizacji rynkowej oraz wartości finansowych. Zawarcie aliansu zapewniło znaczny wzrost rentowności obu firm. W latach 1999-2007 Renault osiągnęło ponad trzykrotny wzrost swojej wartości, z 8,4 mld EUR w 1999 roku do 27,6 mld EUR w 2007 roku. Z kolei wartość koncernu Nissan w tym samym okresie wzrosła czterokrotnie, z 9 mld EUR w 1999 roku do 34,2 mld EUR w 2007 roku (Sulejewicz 2003, „10-ta rocznica aliansu Renault-Nissan", www.wnp.pl z dnia 31.03.2009).

W 2010 roku koncern Renault osiągnął przychody na poziomie 52,2 mld USD, co stanowiło 3,42\% przychodów 28 największych przedsiębiorstw branży motoryzacyjnej świata, jednocześnie osiągając 4,6 mld USD zysków, co stanowiło 8,7\% zysków największych przedsiębiorstw branży motoryzacyjnej. Wartość koncernu Renault w 2010 roku wynosiła 16,7 mld USD, co stanowiło 2,1\% wartości największych przedsiębiorstw branży motoryzacyjnej na świecie (Tab. 5). 
Tab. 5. Największe korporacje motoryzacyjne świata w 2010 roku

\begin{tabular}{|c|c|c|c|c|c|c|c|}
\hline Lp. & $\begin{array}{c}\text { Pozycja } \\
\text { na liście } \\
\text { Forbes } \\
\text { Global } \\
2000 \mathrm{za} \\
2010 \text { rok }\end{array}$ & Nazwa & Kraj pochodzenia & $\begin{array}{c}\text { Przychody } \\
\text { w mld } \\
\text { USD }\end{array}$ & $\begin{array}{l}\text { Zysk } \\
\text { w } \\
\text { mld } \\
\text { USD }\end{array}$ & $\begin{array}{l}\text { Wartość } \\
\text { aktywów } \\
\text { w mld } \\
\text { USD }\end{array}$ & $\begin{array}{c}\text { Wartość } \\
\text { rynkowa } \\
\text { w mld } \\
\text { USD }\end{array}$ \\
\hline 1 & 24 & \begin{tabular}{|l|} 
Volkswagen \\
Group
\end{tabular} & Niemcy & 168,30 & 9,10 & 267,50 & 70,30 \\
\hline 2 & 43 & Daimler & Niemcy & 130,90 & 6,00 & 178,70 & 70,50 \\
\hline 3 & 54 & Ford Motor & USA & 129,00 & 6,60 & 164,70 & 54,30 \\
\hline 4 & 55 & Toyota Motor & Japonia & 202,80 & 2,20 & 323,50 & 137,80 \\
\hline 5 & 61 & General Motors & USA & 135,60 & 6,20 & 138,90 & 49,80 \\
\hline 6 & 72 & BMW Group & Niemcy & 80,20 & 4,30 & 146,10 & 51,00 \\
\hline 7 & 80 & Honda Motor & Japonia & 91,80 & 2,90 & 122,20 & 73,20 \\
\hline 8 & 131 & Hyundai Motor & Korea Południowa & 78,50 & 2,60 & 87,60 & 35,80 \\
\hline 9 & 162 & Renault & Francja & 52,20 & 4,60 & 93,10 & 16,70 \\
\hline 10 & 195 & Volvo Group & Szwecja & 39,40 & 1,60 & 45,50 & 34,80 \\
\hline 11 & 266 & Nissan Motor & Japonia & 80,40 & 0,46 & 107,90 & 40,80 \\
\hline 12 & 307 & Peugeot & Francja & 75,00 & 1,50 & 91,20 & 8,70 \\
\hline 13 & 358 & Fiat Group & Włochy & 48,00 & 0,70 & 96,30 & 10,90 \\
\hline 14 & 407 & SAIC Motor & Chiny & 20,30 & 0,97 & 20,00 & 25,90 \\
\hline 15 & 512 & Tata Motors & Indie & 20,20 & 0,57 & 19,30 & 15,20 \\
\hline 16 & 574 & $\begin{array}{l}\text { Dongfeng Motor } \\
\text { Group }\end{array}$ & Chiny & 13,40 & 0,91 & 12,40 & 14,90 \\
\hline 17 & 618 & Suzuki Motor & Japonia & 26,40 & 0,31 & 24,40 & 13,00 \\
\hline 18 & 1025 & \begin{tabular}{|l} 
Mahindra \\
$\&$ Mahindra
\end{tabular} & Indie & 7,00 & 0,55 & 7,90 & 8,20 \\
\hline 19 & 1037 & BYD & Chiny & 7,10 & 0,38 & 8,10 & 10,20 \\
\hline 20 & 1044 & Mitsubishi Motors & Japonia & 15,50 & 0,05 & 13,40 & 7,40 \\
\hline 21 & 1115 & Mazda Motor & Japonia & 23,20 & $-0,07$ & 19,90 & 4,30 \\
\hline 22 & 1128 & \begin{tabular}{|l|} 
Fuji Heavy \\
Industries
\end{tabular} & Japonia & 15,30 & $-0,18$ & 13,10 & 6,20 \\
\hline 23 & 1135 & Porsche & Niemcy & - & $-0,52$ & 36,70 & 13,50 \\
\hline 24 & 1154 & Isuzu Motors & Japonia & 11,60 & 0,09 & 11,80 & 7,20 \\
\hline 25 & 1356 & $\begin{array}{l}\text { Guangzhou } \\
\text { Automobile }\end{array}$ & Chiny & 7,40 & 0,29 & 6,40 & 7,60 \\
\hline 26 & 1462 & \begin{tabular}{|l|} 
Navistar \\
International
\end{tabular} & USA & 12,10 & 0,20 & 9,30 & 4,70 \\
\hline 27 & 1946 & \begin{tabular}{|l} 
Ford Otomotiv \\
Sanayii
\end{tabular} & Turcja & 5,00 & 0,33 & 2,20 & 3,00 \\
\hline 28 & 1979 & FAW Car & Chiny & 5,50 & 0,26 & 2,60 & 4,30 \\
\hline & & & & 1502,10 & 52,90 & 2070,70 & 800,20 \\
\hline
\end{tabular}

Źródło: opracowanie własne na podstawie Forbes Global za 2010 rok 
W 2010 roku koncern Nissan osiągnął przychody na poziomie 80,4 mld USD, co stanowiło 5,35\% przychodów 28 największych przedsiębiorstw branży motoryzacyjnej, jednocześnie osiągając 460 mln USD zysków, co stanowiło 0,87\% zysków największych przedsiębiorstw branży motoryzacyjnej. Wartość koncernu Nissan w 2010 roku wynosiła 40,8 mld USD, co stanowiło 5,1\% wartości największych przedsiębiorstw branży motoryzacyjnej na świecie.

W 2010 roku alians firm Nissan i Renault osiągnął łączne przychody wynoszące 132,6 mld USD, co stanowiło 8,8\% przychodów branży na świecie, co lokuje go na 4 pozycji pod względem wielkości przychodów wśród największych przedsiębiorstw motoryzacyjnych świata. Alians obu przedsiębiorstw osiągnął w 2010 roku zysk wynoszący 5,06 mld USD (5 miejsce), co stanowiło 9,57\% ogółu zysków największych przedsiębiorstw branży, zaś wartość rynkowa przedsiębiorstw wchodzących w skład aliansu wyniosła w 2010 roku 57,5 mld USD (5 miejsce), co stanowiło 7,19\% wartości największych przedsiębiorstw motoryzacyjnych na świecie.

Należy podkreślić, iż w latach 1999-2010 oba przedsiębiorstwa wchodzące w skład aliansu zwiększyły swoją wartość rynkową, poziom przychodów oraz wielkość zysków, a alians obu przedsiębiorstw stał się czołową firmą motoryzacyjną świata.

Przemiany zachodzące w branży motoryzacyjnej w latach 2000-2010 wskazują, iż branża ta podlega procesom globalizacji, których efektem są m.in. przejęcia, fuzje i alianse strategiczne zawierane między poszczególnymi koncernami. Zmiany te wskazują, iż w branży motoryzacyjnej zachodzą procesy koncentracji i konsolidacji kapitału oraz relokacji i delokalizacji produkcji.

Koncerny Nissan i Renault zawierając w 1999 roku alians strategiczny utworzyły międzynarodową grupę produkującą samochody osobowe w globalnej skali.

Zawarcie porozumienia było dla obu koncernów znaczącym impulsem rozwojowym. Dla koncernu Nissan przeżywającego w 1999 roku poważne problemy finansowe, zawarcie aliansu oddaliło groźbę bankructwa przedsiębiorstwa oraz pozwoliło zintensyfikować działania firmy na terenie Stanów Zjednoczonych. Koncern Nissan uzyskał również dostęp do rozwiniętej sieci sprzedaży koncernu Renault w Europie, wsparcia marketingowego, a także wszedł w posiadanie wiedzy niezbędnej do rozwoju produkcji małych samochodów.

Wraz z zawarciem aliansu, koncern Renault uzyskał dostęp do azjatyckiego i północno-amerykańskiego rynku zbytu. Zawarcie aliansu pozwoliło koncernowi Renault znacznie urozmaicić gamę oferowanych produktów, wprowadzając do produkcji nowe modele samochodów z segmentów lekkich samochodów użytkowych oraz dużych samochodów pasażerskich. Ponadto Renault uzyskał dostęp do specjalistycznej wiedzy i doświadczeń fïmy Nissan w procesie produkcji, podnosząc w analizowanym okresie o ok. 15\% wydajność pracy w swoich zakładach.

Należy zaznaczyć, iż zawierając alians strategiczny zarówno koncerny Nissan jak i Renault, nie konkurowały ze sobą na najważniejszych rynkach zbytu. Koncern Renault posiadał ugruntowaną pozycję w Europie i Afryce Północnej, zaś koncern Nissan w Azji, USA i RPA. Dzięki uzupełnianiu się obszarów rynków zbytu, na których działają koncerny Renault i Nissan, oba koncerny uzyskały globalny zasięg swej działalności.

Rozpatrując zmiany wielkości produkcji koncernów Nissan i Renault w latach 2000 -2010 zauważono stałą tendencję wzrostu produkcji obu przedsiębiorstw, przy czym w analizowanych latach w obu koncernach zaobserwowano procesy delokalizacji i relokacji pro- 
dukcji z macierzystych krajów do krajów o niższych kosztach produkcji i dużych rynkach zbytu. Renault rozpoczął produkcję w Rumunii i Korei Południowej oraz rozwinął produkcję w Brazylii, Nissan rozpoczął produkcję na rynkach azjatyckich, głównie w Chinach oraz w rozwija produkcję w Ameryce Północnej.

W analizowanym okresie czasu oba przedsiębiorstwa wchodzące w skład aliansu znacznie zwiększyły uzyskiwane wyniki finansowe.

Zawarcie aliansu pozwoliło utworzyć mniejszym producentom samochodów osobowych, czwarte pod względem wielkości produkcji przedsiębiorstwo motoryzacyjne świata.

\section{Literatura}

„10-ta rocznica aliansu Renault-Nissan”, www.wnp.pl z dnia 31.03.2009.

„Alians Renault-Nissan i Daimler nawiązują wspólną współpracę”, www.wnp.pl z dnia 07.04.2010.

Alliance Facts \& Figures, 2009 - www.Renault.com, www.nissan-global.com.

Dunning J.H., 1993, Multinational Enterprises and the Global Economy, Addison-Wesley, Wokingham, s. 6.

Dussauge P., Garette B., 1996, Strategie aliansów na rynku, Wyd. Poltext, Warszawa, s. 23.

Ernst \& Young, 2004, Alianse strategiczne - wspótpraca czy rywalizacja?

Forbes 2011, Special Report, The World's 2000 largest Public Companies.

Gomes-Casseres B., Alliances and risk: securing a place in the victory parade, Financial Times, May 9, 2000.

Kola M, Kuzel M., 2006, Fuzje, przejęcia i alianse strategiczne jako alternatywne formy internacjonalizacji działalności przedsiębiorstw $w$ warunkach globalizacji gospodarki światowej, [w:] Współczesne zjawiska w gospodarce, T. Koźliński (red.), Wyd. UMK, Toruń, s. 1-15.

Kraciuk J., 2005, Alianse strategiczne jako sposób konsolidacji przedsiębiorstw, Prace Naukowe Nr 28 Katedry Polityki Agrarnej i Marketingu SGGW, Wyd. SGGW, Warszawa, s. 498-506.

Narula R., 2003, Globalisation and Trends in International R\&D Alliances, Copenhagen Bussines School \& MERIT, Working Paper 1-2003, s. 2.

Nissan Annual Report 2009-2010.

Nissan Profile 2007-2008.

Nyga L., Rozwój zewnętrzny przedsiębiorstw widziany przez pryzmat aliansów strategicznych, http:// www.knfm.friko.pl/prace-Dateien/Nyga\%20Lidia.doc z dnia 15.10.2011.

OICA, World Motor Vehicle Production, 1998-2010.

OICA, World Motor Vehicle Production, Oica World Ranking of Manufacturers 1998-2010.

Renault Annual Report 2000-2010.

RENAULT registration document 2007.

"Renault-Nissan Close to Taking Control of AvtoVAZ?", http://autobeatinsider.com/news/renault-nissan-close-to-taking-control-of-avtovaz, 16.06.2011.

„Renault-Nissan: w stronę wzmocnienia aliansu”, www.wnp.pl z dnia 29.05.2009.

Romanowska M.,1997, Alianse strategiczne przedsiębiorstw, Wyd. PWE, Warszawa.

Rymarczyk J. (red.), 2006, Międzynarodowe stosunki gospodarcze, Wyd. PWE, Warszawa.

Sulejewicz A., 2003, Compare the two mergers: Daimler-Chrysler and Renault-Nissan. Any implications for the IMGT framework?, European Strategies and International Business.

Zioło Z., 2006, Zróżnicowanie światowej przestrzeni przemysłowej w świetle koncentracji siedzib zarządów wiodących korporacji, [w:] Z. Zioło, T. Rachwał (red.), Międzynarodowe uwarunkowania rozwoju przemystu, Prace Komisji Geografii Przemysłu Polskiego Towarzystwa Geograficznego, nr 8, Warszawa-Kraków, s. 9-26. 


\section{Development of Nissan and Renault strategic alliance}

The advancing process of economic globalization and the related increase in market competitiveness compels companies to search for new markets. Internationalisation processes present in all world-economy sectors, including the automotive industry, are manifested in such phenomena as entering into strategic alliances and the change of world corporations production structures. In the world economy, alliances are entered into mainly by high technology enterprises, such as telecommunication, information technology, aviation and automotive industries.

In numerous companies, in particular in trans-national ones, there is a tendency to get involved in cooperative activity, carrying out mergers or concluding strategic alliances. Corporate strategic alliances result in the emergence of various space and production links through the creation of network connection systems, organizing world economic space at the same time.

Consequently, changes occur in the ownership structure of concerns (concentration of capital), and relocation and delocalization of world production take place.

In this context, this article analyses the process of shaping and functioning of the strategic alliance between Nissan and Renault international automotive corporations, as well as presents the benefits of the strategic alliance formed by the mentioned companies.

\section{Mgr Piotr Lizak}

Uniwersytet Pedagogiczny w Krakowie

Instytut Geografii

Zakład Przedsiębiorczości i Gospodarki Przestrzennej

e-mail: Lizak.Piotr@wp.pl 